\title{
Pengomposan Limbah Peternakan Sapi Potong Menggunakan Bioaktivator Asal Limbah Rumah Tangga Organik sebagai Upaya Meningkatkan Sanitasi Lingkungan di Kelompok Ternak Mulya Abadi Kertajati Majalengka
}

\section{Composting Beef Cattle Farm Waste Using Bioactivators from Organic Household Waste as Efforts to Improve Environmental Sanitation in the Mulya Abadi Kertajati Majalengka Livestock Group}

\author{
Oki Imanudin ${ }^{1, a}$, Dini Widianingrum ${ }^{1}$, Aaf Falahudin ${ }^{1}$ \\ ${ }^{1}$ Program Studi Peternakan Fakultas Pertanian Universitas Majalengka \\ aemail: okiimanudin@unma.ac.id
}

\begin{abstract}
Abstrak
Kelompok Ternak Mulya Abadi merupakan kelompok usaha ternak potong beranggotakan 34 orang yang berlokasi di Dusun Kertamulia, Desa Mekar Jaya, Kecamatan Kertajati Kabupaten Majalengka. Pemeliharaan ternak bersifat intensif yaitu pola pemeliharaan sapi dengan cara dikandangkan. Pola pemeliharaan ini menghasilkan limbah peternakan sapi potong yang terkonsentrasi di sekitar kandang. Di sisi lain, keluarga peternak pun menghasilkan limbah rumah tangga organik. Pengolahan limbah hanya dilakukan dengan cara dibiarkan tanpa ada penanganan lebih lanjut, kedua jenis limbah tersebut akan menjadi sumber pencemaran lingkungan yang berdampak pada kesehatan. Pentingnya kesadaran masyarakat dalam menjaga lingkungan yang bersih perlu dilakukan upaya pendampingan dan pembinaan, salah satu caranya yaitu dengan penyuluhan pemanfaatan dan pengolahan limbah peternakan sapi potong dan limbah rumah tangga secara terpadu melalui teknik pengomposan dengan memanfaatkan limbah rumah tangga organik sebagai bioaktivator untuk mempercepat proses pengomposan, sehingga sanitasi lingkungan tetap terjaga sekaligus terciptanya peternakan yang ramah lingkungan dengan mengusung konsep zero waste. Penyuluhan dalam kegiatan ini yaitu metode demplot dan pembinaan Kelompok Ternak Mulya Abadi dan ibu-ibu PKK Desa Mekar Jaya Kecamatan Kertajati secara berkala. Penyuluhan dilakukan secara kontinyu dalam kurun waktu 3-4 bulan, melalui pertemuan, diskusi dan praktek pemilahan limbah rumah tangga organik, pembuatan bioaktivator dan proses pembuatan kompos.
\end{abstract}

Kata Kunci: Limbah Sapi Potong, Limbah Rumah Tangga Organik, Bioaktivator, Pengomposan, Kompos

\begin{abstract}
Mulya Abadi Livestock Group is a beef cattle business group with 34 members located in Kertamulia Hamlet, Mekar Jaya Village, Kertajati District, Majalengka Regency. The maintenance of livestock is intensive, namely the pattern of raising cattle by being penned. This maintenance pattern produces beef cattle livestock waste which is concentrated around the pen. On the other hand, farming families also produce organic household waste. Waste treatment is only carried out by leaving it without further treatment, both types of waste will be a source of environmental pollution that has an impact on health. The importance of public awareness in maintaining a clean environment needs assistance and guidance efforts, one of the ways is by counseling the utilization and processing of beef cattle livestock waste and household waste in an integrated manner through composting techniques by utilizing organic household waste as a bio-activator to accelerate the composting process so that environmental sanitation is maintained as well as creating environmentally friendly farms by carrying out the concept of zero waste. The counseling in this activity is the demonstration plot method and the training of the Mulya Abadi Livestock Group and PKK Mekar Jaya Village mothers, Kertajati District. The extension is carried out continuously over for period of 3 - 4 months, through meetings, discussions, and practice of sorting organic household waste, making bioactivators, and composting processes.
\end{abstract}

Key words: Beef Cattle Waste, Organic Household Waste, Bioactivator, Composting, Compost 


\section{Pendahuluan}

Kelompok ternak Mulya Abadi beranggotakan 34 orang yang terletak di Dusun Kertamulia Desa Mekar Jaya Kecamatan Kertajati Kabupaten Majalengka Provinsi Jawa Barat memelihara ternak sapi potong sebagai mata pencaharian sampingan dan sebagai penghasilan tambahan dari bertani, pola pemeliharaannya pun masih sederhana/konvensional dengan skala kepemilikan rata-rata sebanyak 2-4 ekor, pemeliharaan ternak bersifat intensif yaitu pola pemeliharaan sapi dengan cara dikandangkan, pola pemeliharaan ini berdampak pada limbah yang terkonsentrasi disekitar kandang.

Selama ini pengolahan limbah sapi potong di kelompok Mulya Abadi hanya diolah seadanya dengan cara dikumpulkan dan dibiarkan tertumpuk diudara terbuka tanpa ada pengolahan lebih lanjut hanya mengandalkan proses penguraian secara alami, sehingga waktu pengomposan relatif lama sekitar 3-6 bulan. Setelah kompos matang, kompos hanya dimanfaatkan oleh para anggota kelompok untuk memupuk sawah garapannya. Selama pengomposan secara alami ini berlangsung terjadi proses fermentasi yaitu penguraian bahan-bahan organik oleh mikroorganisme alami yang akan melepaskan senyawa-senyawa yang mengakibatkan terjadinya penguapan, gas yang dihasilkan oleh adanya aktivitas mikroorganisme ini menimbulkan aroma yang sedikit menyengat dan cenderung bau karena gas tersebut mengandung ammonia yang dihasilkan dari asimilasi pakan ternak, terlebih pada saat musim penghujan, akan memicu pertumbuhan larva lalat, yang dapat mengakibatkan berbagai macam penyakit dan masalah kesehatan baik bagi peternak, lingkungan maupun bagi ternak itu sendiri. Kondisi seperti ini menjadi persoalan seruis bagi kelompok Ternak Mulya Abadi karena dapat memicu protes dari warga sekitar.

Peran lain para ibu peternak tidak dapat dipisahkan dari kehidupan beternak, seperti membersihkan kandang, dan membantu mencari pakan, disamping tugas pokoknya sebagai ibu rumah tangga. Kegiatan rumah tangga di dapur pun tak luput dari aktivitas menghasilkan limbah seperti sisa makanan, sisa kegiatan memasak, sisa sayur dan lain sebagainya. Semua limbah tersebut akan menumpuk dan akan mengalami pembusukan yang tanpa disadari limbah ini pun terkonsentrasi pada masing-masing kepala keluarga dalam jumlah yang cukup banyak dan jika tidak ditangani dengan baik akan menimbulkan bau dan mencemari lingkungan sekitar.

Sehubungan dengan hal tersebut perlu penanganan dari kedua permasalahan limbah secara terpadu, diantaranya melalui penyuluhan tentang teknik pengomposan. Teknik pengomposan yang digunakan yaitu proses pengomposan limbah sapi potong dengan cara rekayasa aktivitas mikroba pembusuk, mikroba pembusuk ini berperan sebagai bioaktivator yang dapat mempersingkat waktu pengomposan, bioaktivator yang digunakan pada teknik pengomposan ini yaitu berasal dari fermentasi limbah rumah tangga organik atau lebih dikenal dengan mikroorganisme lokal (MOL) sehingga akan menghasilkan produksi kompos yang relative cepat, berkualitas, memiliki nilai ekonomi sehingga menjadi pendapatan tambahan bagi kelompok dan sanitasi lingkungan terwujud.

Tujuan dari kegiatan ini yaiu memberikan penyuluhan dan pelatihan kepada kelompok ternak beserta istri yang tergabung dalam kelompok PKK mengenai teknik rekayasa pengomposan menggunakan bioaktivator asal limbah rumah tangga sehingga diharapkan dapat memberikan keterampilan dan dapat menghasilkan penghasilan tambahan bagi keluarga peternak melalui bioaktivator dan kompos yang dihasilkan. Selain itu dapat terciptanya kondisi peternakan sehat yang ramah lingkungan.

\section{Materi dan Metode Pelaksanaan}

Metode Pelaksanaan kegiatan ini dilakukan dengan cara mengkoordinasikan terlebih dahulu dengan ketua kelompok Mulya Abadi terkait teknis dimana akan dilaksanakan kegiatan pekatihan ini. Sebelum penyuluhan dilaksanakan, dilakukan Pre-Test kepada anggota 
kelompok sebagai peserta penyuluhan terlebih dahulu. Setelah itu, dilakukan penyuluhan dengan metoda ceramah tentang keadaan lingkungan dan materi mengenai Pemanfaatan limbah rumah tangga organik yang digunakan sebagai bioaktivator dalam pengomposan limbah sapi potong. Kemudian dilakukan demonstrasi cara serta diskusi mengenai pembuatan bioaktivator dan pembuatan kompos limbah peternakan sapi potong dan kegiatan diakhiri dengan Post- Test.

Kegiatan penyuluhan dilaksanakan di Saung pertemuan kelompok ternak Mulya Abadi pelaksanaannya diawali dengan melaksanakan pre-test, penyampaian materi, dan diskusi. Pelatihan pembuatan bioaktivator dari sampah organik dan pembuatan pupuk organik dilakukan bersama-sama dengan membuat demplot oleh anggota kelompok ternak. Kualitas pupuk organik hasil produksi peternak dianalisis di Laboratorium Balai Penelitian Tanaman Sayuran (Balitsa) Bandung.

\section{Hasil dan Pembahasan}

Kegiatan penyuluhan kelompok ternak Mulya Abadi telah terlaksana dengan baik. Kegiatan penyuluhan diawali dengan sosialisasi penyuluhan tentang budidaya ternak sapi potong yang sehat dan berwawasan lingkungan serta alternatif pemanfaatan limbah peternakan menjadi kompos melalui pemanfaatan bioaktivator

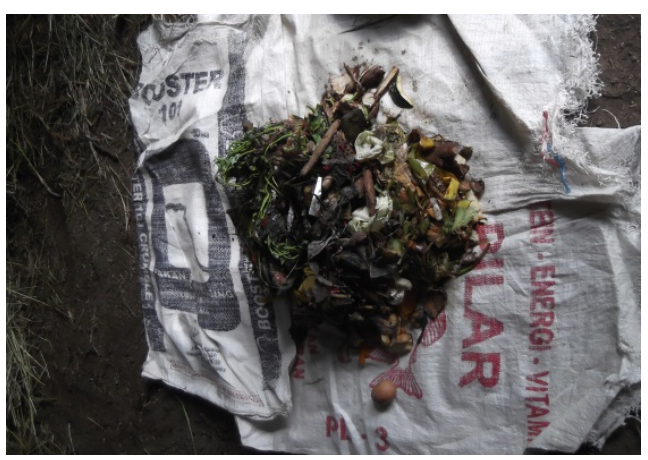

Gambar 1. Limbah Rumah Tangga limbah rumah tangga. Kegiatan sosialisasi ini bertujuan menambah pengetahuan peternak sehingga memiliki persepsi positif tentang usaha ternak ramah lingkungan serta menumbuhkan sikap dan tindakan yang positif sehingga setelah pelatihan, para peternak mampu melakukan pengelolaan usaha ternak sapi potong secara optimal dan berkelanjutan. Anggota kelompok yang mengikuti sosialisasi sebanyak $85 \%$ dari total anggota kelompok,

\section{Pendampingan dan bimbingan teknis pengolahan limbah rumah tangga organik}

Penyuluhan dilaksanakan dengan cara pendampingan dan pengarahan serta bimbingan teknis mengenai prosedur pengolahan limbah organik rumah tangga menjadi bioaktivator, sebagai berikut: Memberikan penjelasan tentang pentingnya memilih dan memilah sampah rumah tangga (organik maupun anorganik), limbah organik yang telah dikumpulkan kemudian dihomogenkan dan dicampur dengan bahan lain, kemudian masukan kedalam karung.

Selanjutnya membuat larutan bioaktivator dalam tong (drum) yang terdiri dari: Feses \pm 10 liter, gula merah $1 / 2 \mathrm{~kg}$, air cucian dan sampah organik, tutup rapat selama 7-14 hari (fermentasi), bila sudah matang bioaktivator memiliki bau masam (menyerupai bau tapai/peuyeum) dan bioaktivator siap digunakan sebagi starter dalam pengomposan limbah peternakan sapi potong.

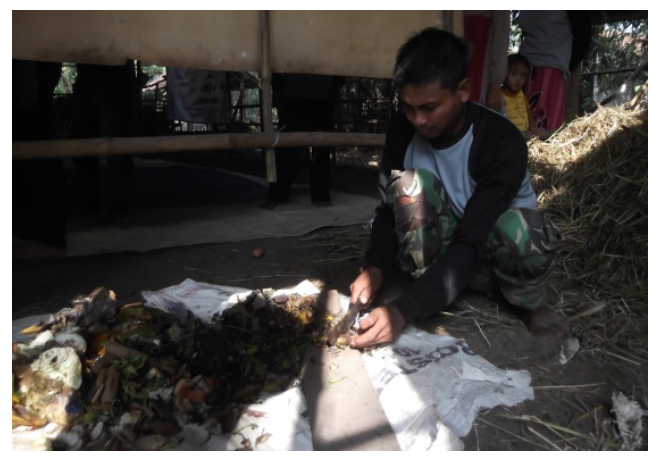

Gambar 2. Homogenisasi 


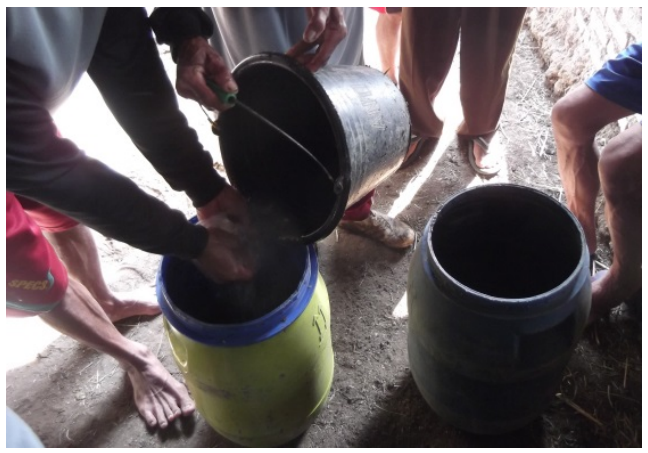

Gambar 3. Membuat larutan

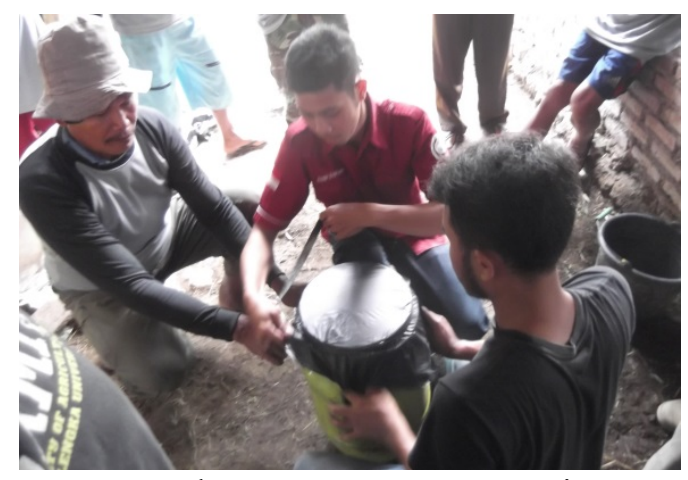

Gambar 5. Proses Fermentasi

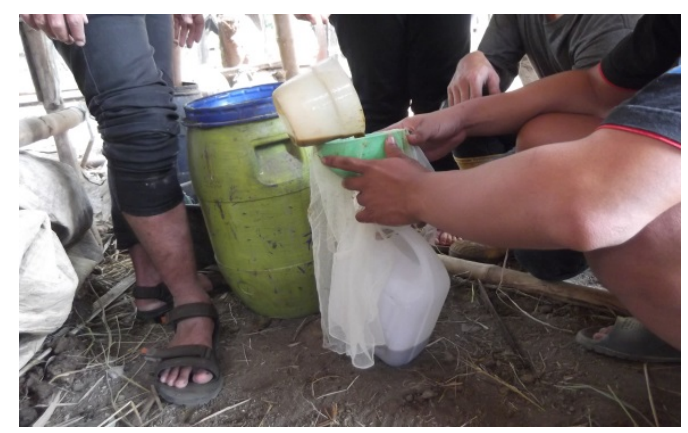

Gambar 7. Penyaringan

Setelah peserta memahami dan mampu memanfaatkan serta membuat bioaktivator dengan bahan dasar limbah rumah tangga organik, maka diharapkan dapur ibu-ibu PKK (istri peternak) kelompok ternak mulya abadi menjadi lebih bersih, kemudian dapat bersinergi dengan anggota kelompok ternak (suami) sebagai penyedia bioaktivator dalam mengolah limbah peternakan sapi potong sehingga terjalin hubungan kontribusi yang positif di internal keluarga para peternak yang tergabung dalam kelompok ternak Mulya Abadi

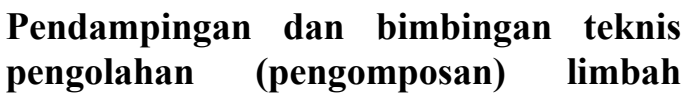

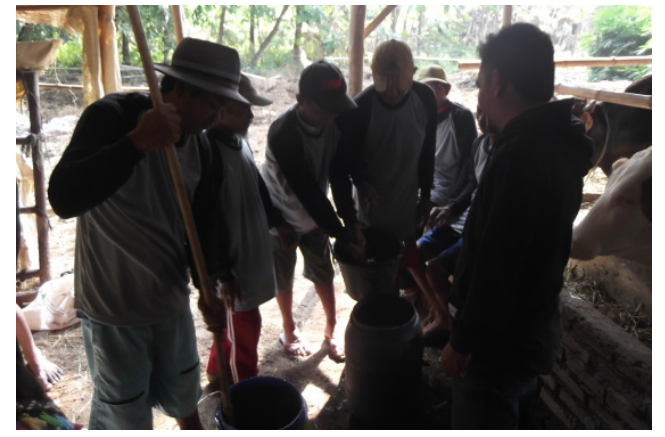

Gambar 4. Pengadukan Bioaktivator

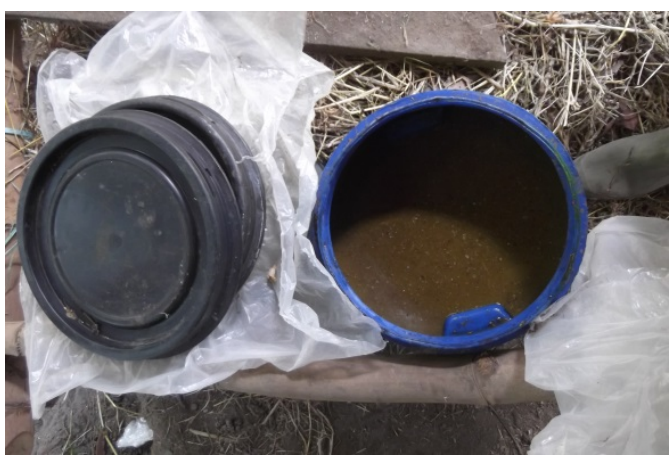

Gambar 6. Bioaktivator setelah fermentasi

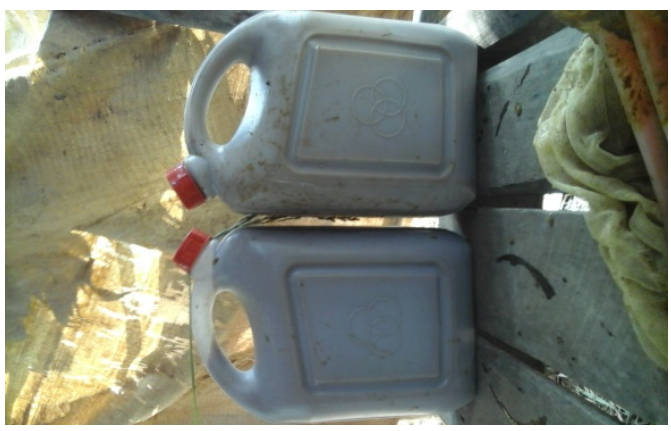

Gambar 8. Bioaktivator LRT

\section{peternakan sapi potong menggunakan bioaktivator}

Pengolahan limbah peternakan sapi potong yang ada di Kelompok ternak Mulya abdi masih dibiarkan menumpuk sebelum dimanfaatkan menjadi kompos, sehingga waktu pengomposan berjalan dengan sangat lambat. Melalui penyuluhan dengan cara pendampingan dan bimbingan teknis secara intensif bagi Kelompok ternak Mulya Abadi tentang pengolahan (pengomposan) limbah peternakan sapi potong menggunakan bioaktivator dari limbah rumah tangga organik, dengan langkah-langkah sebaga berikut: Feses dibersihkan dari kandang dan dikumpulkan di saung kompos dan ditumpuk diatas segitiga aerasi dengan 
ketinggian 1 meter, panjang 5 meter dan lebar 3 meter (sesuai kebutuhan). Tumpukan terdiri dari dua jenis lapisan yaitu lapisan pertama feses setebal $10-15 \mathrm{~cm}$ kemudian tambahkan bioaktivator asal limbah rumah tangga organik dengan cara disemprot menggunakan sprayer selanjutnya menumpukan sisa pakan yang sudah dichoper diatas feses sebagai lapisan kedua, kemudian tumpuk lagi feses dan selanjutnya seperti itu hingga tumpukan setinggi $1 \mathrm{~m}$.

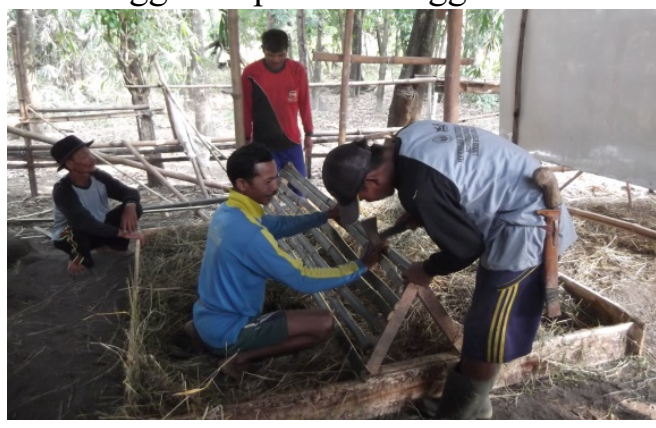

Gambar 9. Pembuatan Aerator

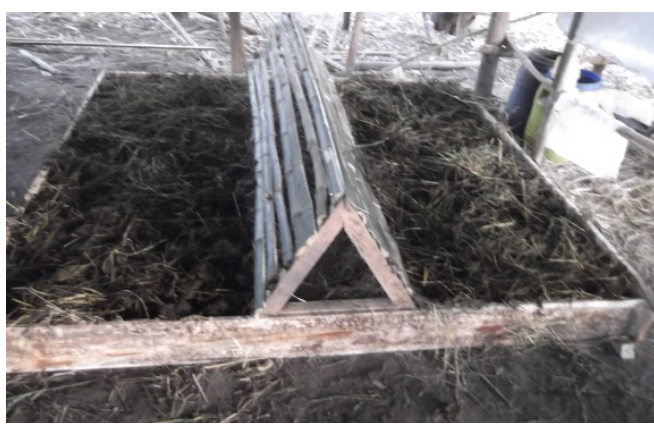

Gambar 11. Tumpukan Kompos

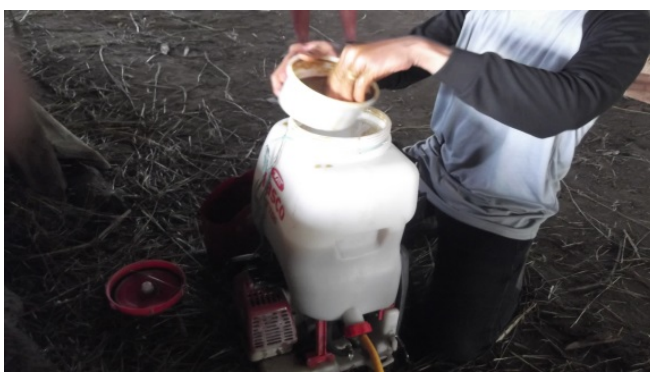

Gambar 13. larutan dimasukan kedalam

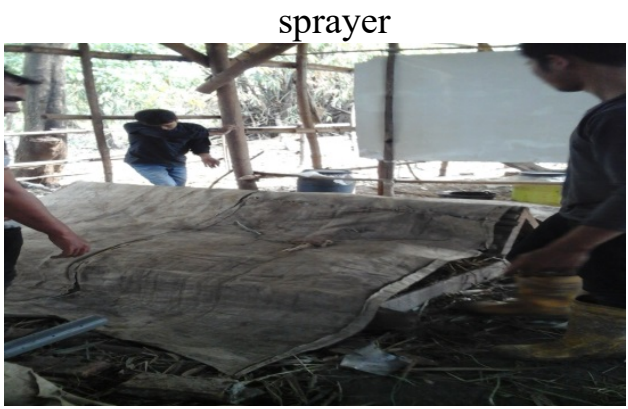

Pengontrolan suhu, $\mathrm{pH}$ dan kelembaban diamati tiga hari sekali suhu idel yaitu 50-60 ${ }^{0} \mathrm{C}$, sambil dilakukan pembalikan untuk meminimalisir kenaikan suhu melebihi suhu optimal Firman, 2010), jika bahan komposan terlalu kering $<50 \%$ lakukan penyemprotan menggunakan air. Jika bahan terlalu asam tambahkan kapur untuk menstabilkan $\mathrm{pH}$, pengomposan berlangsung selama $14-21$ hari.

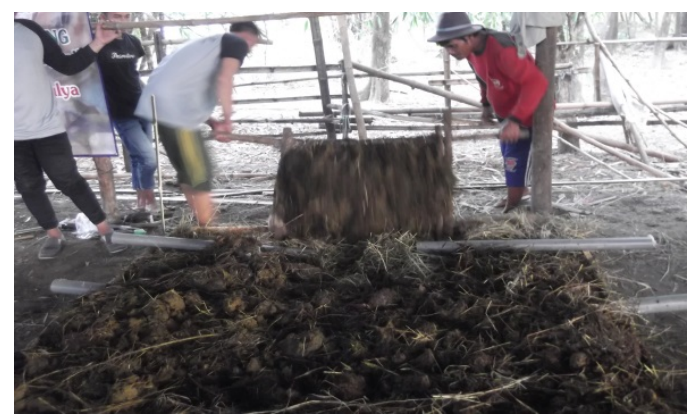

Gambar 10. Collection limbah (feses dan

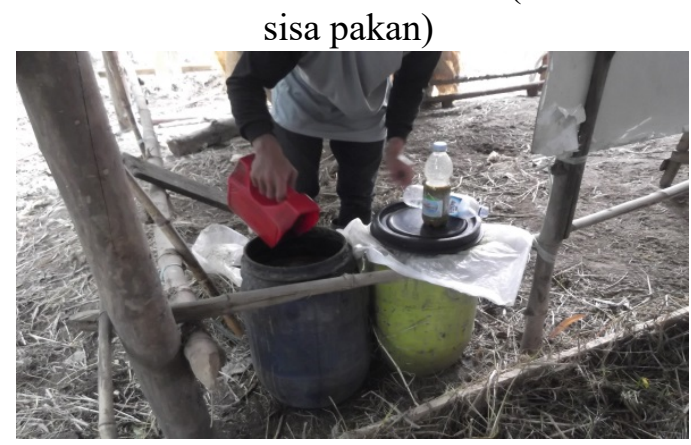

Gambar 12. Membuat larutan bioaktivator



Gambar 14. Pengaplikasian Bioaktivator dalam pengomposan

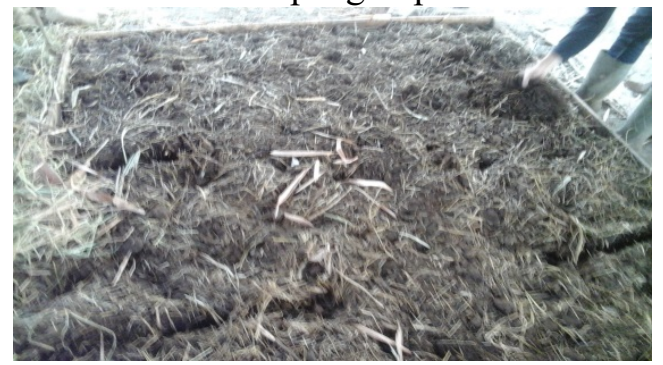




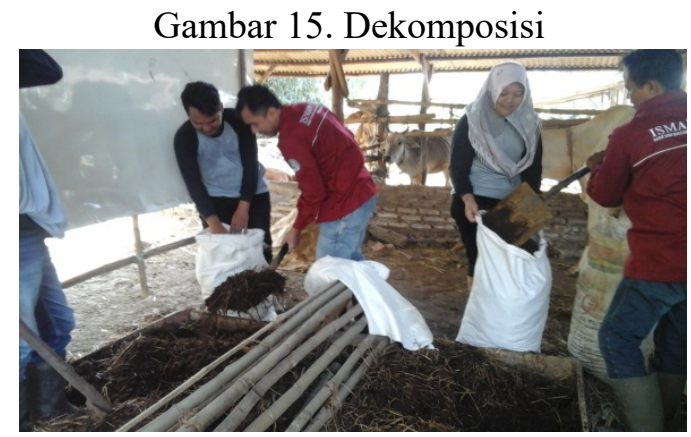

Gambar 17. Pemanenan Kompos

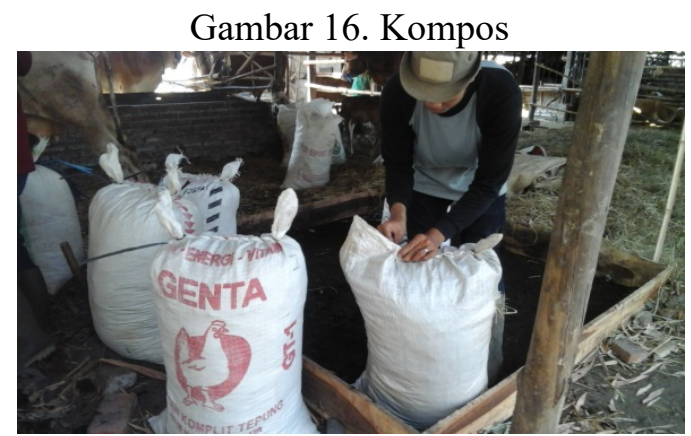

Gambar 18. Mengemas Kompos

Tabel 1. Kandungan $\mathrm{N}$ total, $\mathrm{P}_{2} \mathrm{O}_{5}$ dan $\mathrm{K}_{2} \mathrm{O}$ kompos feses sapi potong dengan penambahan bioaktivator dari limbah rumah tangga organik dibandingkan dengan tanpa penambahan bioaktivator

\begin{tabular}{lccc}
\hline \multirow{2}{*}{ Perlakuan } & \multicolumn{3}{c}{ Rataan (\%) } \\
\cline { 2 - 4 } & $\mathrm{N}$ & $\mathrm{P}_{2} \mathrm{O}_{5}$ & $\mathrm{~K}_{2} \mathrm{O}$ \\
\hline Tanpa Bioaktivator & 0,63 & 0,38 & 0,23 \\
Penambahan Bioaktivator & 1,09 & 0,62 & 0,50 \\
\hline
\end{tabular}

Berdasarkan hasil kegiatan pembuatan kompos yang dilakukan di kelompok ternak Mulya Abadi diperoleh kandungan unsur hara Nitrogen total $(\mathrm{N}-$ total), $\mathrm{P}_{2} \mathrm{O}_{5}$ dan $\mathrm{K}_{2} \mathrm{O}$ kompos tersaji pada Tabel berikut.

Mengacu pada SNI 19-7030-2004 tentang standar kualitas kompos maka kompos yang dibuat di kelompok Ternak Mulya Abadi telah sesuai dengan syarat minimal kompos (SNI) tersebut. Hal ini diduga karena penambahan bioaktivator pada pengomposan feses sapi potong terjadi pendekomposisian bahan organik secara baik oleh aktivitas mikroorganisme yang terdapat dalam bioaktivator limbah rumah tangga organik tersebut, kondisi ini menggambarkan penambahan bioaktivator pada pengomposan mengakibatkan proses penguraian bahan oganik semakin cepat. Hal ini sejalan dengan penelitian Mbouobda et al. (2014) bahwa penambahan effective microorganism pada proses pengomposan dapat mempercepat proses pengomposan.

\section{Monitoring dan Evaluasi}

Monitoring dan evaluasi dilakukan secara berkala pada setiap proses kegiatan. Pada saat monitoring diuraikan tentang proses yang terjadi serta kegagalan dan hambatan yang terjadi disebabkan oleh berbagai faktor. Berbagai solusi dan pencegahan kegagalan didiskusikan dengan para peserta penyuluhan.

\section{Evaluasi Pengetahuan Peternak}

Test awal (Pre-Test) dilakukan sebelum kegiatan penyuluhan pertanian yang dilaksanakan 7 hari sebelum pelaksanaan penyuluhan. Adapun tujuan pelaksanaan Test awal (Pre- Test) adalah untuk mengetahui tingkat pengetahuan peternak dalam pengaplikasian bioaktivator dalam rekayasa pengomposan limbah peternakan khususnya peternakan sapi potong. Jumlah responden dalam tes awal (Pre-Test) adalah 30 orang dengan jumlah pernyataan sebanyak 20 pertanyaan.

Test akhir (Pre-Test) dilakukan setelah kegiatan penyuluhan hal ini dilakukan untuk mengetahui pengetahuan peternak dalam mengaplikasikan bioaktivator asal limbah rumah tangga organik dalam pengomposan limbah peternakan sapi potong menjadi kompos serta dapat menjaga lingkungan dan meningkatkan sanitasi lingkungan disekitar kandang.

Dalam pelaksanaan evaluasi terdapat 30 orang dengan jumlah pernyataan sebanyak 20 pertanyaan. Nilai hasil evaluasi saat Pre_Test adalah 1356. sedangkan nilai PostTest mencapai 1554, sehingga terjadi peningkatan pengetahuan peternak setelah dilaksanakan penyuluhan sebesar 198. 
Peningkatan nilai rekapitulasi Pre-Test dan Post-Test menunjukkan adanya peningkatan pengetahuan peternak stelah mengikuti seluruh rangkaian kegiatan penyuluhan yang sudah dilaksanakan. Materi penyuluhan yang diberikan kepada peternak dapat diterima dengan baik sehingga mampu menambah pengetahuan yang dimiliki peternak terutama dalam melakukan rekayasa pengomposan limbah peternakan sapi potong menggunakan bioaktivator asal limbah rumah tangga organik dapat meningkatkan sanitasi lingkungan

\section{Persepsi Anggota Kelompok}

Setelah mengikuti kegiatan ini anggota kelompok ternak Mulya Abadi menjadi memiliki keterampilan dalam mengelola limbah peternakan yang dihasilkannnya, hal ini terlihat dari aktivitas di kandang yang lebih bersih dan lingkungan kandang terlihat tampak tertata dan lebih bersih, saluran kandang dan sanitasi kandang menjadi berfungsi kembali hal ini berdampak hilangnya bau yang ditimbulkan dari feses yang ditumpuk sehingga lingkungan peternakan menjadi lebih nyaman dan terjadinya sinergitas antara keluarga peternak dalam menciptakan kondisi rumah tangga dan kandang yang nyaman.

\section{Kesimpulan}

Mitra mendapatkan keterampilan dalam memanfaatkan limbah organik menjadi bioaktivator dan bioaktivator. Bioaktivator dimanfaatkan untuk mempercepat proses pengomposan sebagai starter dengan waktu pengomposan relatif singkat yaitu 14 hari.

\section{Ucapan Terimakasih}

Ucapan terima kasih kepada DRPM Dikti yang telah membiayai kegiatan PKM ini, Universitas Majalengka yang telah memberikan kesempatan kepada kami dalam melaksanakan tri dharma perguruan tinggi melalui kegiatan Pengabdian Kepada Masyarakat serta ucapan terimakasih kami sampaikan kepada seluruh warga dan kelompok ternak meliputi kelompok ternak Mulya Abadi dan anggota PKK Desa Mekarjaya Kecamatan Kertajati Kabupaten Majalengka yang telah bersedia menjadi mitra dan para Mahasiswa Prodi Peternakan Fakultas Pertanian Universitas Majalengka yang telah terlibat dalam kegiatan ini.

\section{Daftar Pustaka}

BPS, 2015, Kabupaten Majalengka dalam Angka, Diterbitkan oleh BPS Kabupaten Majalengka. Majalengka.

Badan Standardisasi Nasional Indonesia (SNI). 2004. Spesifikasi Kompos dari Sampah Organik Domestik. 19-70302004.

Crawford, J.H. 2003. Composting of Agricultural Waste. in Biotechnology Applications and Research, Paul N, Cheremisinoff and R. P.Ouellette.

Marlina, E.T., Hidayati, Y.A., Benito, T.B., dan Harlia, E. 2010. Pengaruh Campuran Feses Sapi Pototng dan Feses Kuda Pada Proses Pengomposan Terhadap Kualitas Kompos. Jurnal Ilmu-ilmu Peternakan, XIII (6), 299-303.

Mbouobda, H. D., Fotso, F. O. T. S. O., Djeuani, C. A., Baliga, M.O., \& Omokolo, D. N. 2014. Comparative evaluation of enzyme 
activities and phenol content of Irish potato (So- lanum tuberosum) grown under EM and IMO manures Bokashi. International Journal of Biological and Chemical Sciences, 8(1), 157-166.

Sahwan L Firman. 2010. Kualitas Produk Kompos dan Karakteristik Proses Pengomposan Sampah Kota Tanpa Pemilahan Awal. J. Tek. Ling. Vol. 11 No. $1.79-85$
Sari J, Indah N dan Helyi Y. 2015. Persepsi Petani Terhadap Kinerja Penyuluh dalam Pengembangan Padi Organik di Kecamatan Pagelaran Kabupaten Pringsewu. Jurusan Agribisnis. Fakultas Pertanian. Universitas Lampung JIIA, Vol.3 No. 4 